\title{
EFEKTIVITAS METODE PEMBELAJARAN QUIZ TEAM PADA MATAKULIAH LOGIKA KOMPUTER DITINJAU DARI MOTIVASI BELAJAR MAHASISWA
}

\author{
Nurbani \\ STKIP PGRI Pontianak \\ Nurbani05@gmail.com \\ Herminarto Sofyan \\ Universitas Negeri Yogyakarta \\ hermin@uny.ac.id
}

\begin{abstract}
Abstrak
Penelitian bertujuan untuk mengetahui: 1) perbedaan hasil belajar mahasiswa pada matakuliah Logika Komputer antara kelas yang menggunakan metode pembelajaran quiz team dengan kelas yang menggunakan metode konvensional, (2) perbedaan hasil belajar mahasiswa pada matakuliah Logika Komputer antara kelas yang menggunakan metode pembelajaran quiz team dengan kelas yang menggunakan metode konvensional ditinjau dari motivasi belajar, (3) interaksi antara metode pembelajaran dan motivasi belajar dalam pengaruhnya terhadap hasil belajar. Jenis penelitian adalah eksperimen semu (quasi-experimental research). Desain penelitian yang digunakan Nonequivalent Comparison-group Desig. Sampel dalam penelitian ini berjumlah 2 kelas yang dipilih dari 6 kelas secara acak untuk dijadikan kelas kontrol dan kelas eksperimen. Pengumpulan data menggunakan angket motivasi dan tes hasil belajar. Teknik analisis data yang digunakan dalam penelitian ini menggunakan analisis Anava Dua Jalur. Hasil penelitian menunjukkan: (1) terdapat perbedaan hasil belajar mahasiswa pada matakuliah Logika Komputer dengan kelas yang menggunakan metode pembelajaran quiz team antara kelas yang menggunakan metode konvensional $\left(F_{\text {ratio }}(14,788)>F\right.$ tabel $(3,99))$, (2) terdapat perbedaan hasil belajar mahasiswa terhadap matakuliah Logika Komputer antara kelas yang menggunakan metode pembelajaran quiz team dengan kelas yang menggunakan metode konvensional ditinjau dari motivasi belajar (kelompok motivasi tinggi harga p value $=(0,042$ $<0,05)$ kelompok motivasi rendah harga $p$ value $=0,032<0,05)$ ), dan (3) tidak terdapat interaksi antara metode pembelajaran dan motivasi belajar dalam pengaruhnya terhadap hasil belajar ( $F_{\text {ratio }}$ $\left.(0,450)<F_{\text {tabel }}(3,99)\right)$.
\end{abstract}

Kata kunci: efektivitas, metode pembelajaran, motivasi belajar, hasil belajar

\section{EFFECTIVENESS QUIZ TEAM LEARNING METHODE AGAINTS COMPUTER LOGIC COURSE JUDGING FROM THE STUDENT LEARNING MOTIVATION}

\begin{abstract}
The study aimed to find out: (1) differences in student learning outcomes at the course Logic Computer between the classroom teaching methods and classroom quiz team using conventional methods, (2) differences in student learning outcomes at the course between the Computer Logic class that uses learning methods quiz team as well as the class that uses the conventional method in terms of motivation to learn, (3) the interaction between learning method and motivation in their influence on learning outcomes. This study was a quasi-experimental study (quasi-experimental research). Experimental design used in this study using Nonequivalent Comparison-group Design. The sample in this study amounted to 2 randomly selected classes from 6 classes to serve as the control and the experimental class. Data analysis technique used in this study using Anava two ways analysis The results indicate that: (1) there is a difference in student learning outcomes at the course Logic Computers in classroom teaching methods and classroom quiz team using the conventional
\end{abstract}


method $\left(F_{\text {ratio }}(14,788)>F_{\text {tabel }}(3,99)\right)$, (2) there are differences in student learning outcomes in the course of Computer Logic class that uses learning methods quiz team and a class that uses the conventional method in terms of motivation to learn (high motivation team $p$ value $=(0,042<0,05$ ) low motivation team $p$ value $=0,032<0,05)$ ), and (3) there is no interaction between method of learning and motivation to learn in their influence on learning outcomes $\left(F_{\text {ratio }}(0,450)<F_{\text {tabel }}(3,99)\right)$

Keywords: effectiveness, methods of learning, motivation to learn, learning outcomes

\section{PENDAHULUAN}

Salah satu perguruan tinggi yang ada Kalimantan Barat yaitu Sekolah Tinggi Keguruan Ilmu Pendidikan Persatuan Guru Republik Indonesia (STKIP PGRI) Pontianak merupakan perguruan tinggi swasta yang mana telah memiliki 10 program studi. Salah satu program studi yang ada di STKIP PGRI Pontianak adalah Teknologi Informasi dan Komputer (TIK). Berdasarkan hasil observasi yang dilakukan pada program studi TIK, terdapat matakuliah Logika Komputer pada semester 2 dimana matakuliah tersebut masih banyak mahasiswa yang memiliki nilai rendah. Rata-rata nilai keseluruhan mahasiswa pada matakuliah Logika Komputer semester 2 yaitu 58,9 atau grade D. Ini menunjukkan bahwa hasil belajar mahasiswa matakuliah Logika Komputer masih rendah, sedangkan nilai yang diharapkan untuk matakuliah ini minimal 60 atau grade $\mathrm{C}$.

Berdasarkan hasil wawancara dengan 8 orang mahasiswa yang telah menempuh matakuliah Logika Komputer pada bulan September 2013, metode pembelajaran yang digunakan oleh dosen adalah metode konvensional yaitu ceramah, tanya jawab, dan tugas. Metode pembelajaran ini lebih cenderung ke teacher centered dari pada student centered sehingga masih terpaku pada dosen. Metode pembelajaran ini waktu yang ada kurang dimanfaatkan untuk keaktifan belajar, tetapi hanya mendengarkan dan mencatat keterangan-keterangan matakuliah yang dibicarakan oleh dosen. Hal ini menyebabkan dosen sebagai pemeran yang dominan dalam proses belajar dan mengajar. Metode pembelajaran konvensional pada matakuliah Logika Komputer kurang mampu menarik perhatian dan memotivasi mahasiswa untuk aktif dalam pembelajaran. Suasana belajar monoton dan kurang menggairahkan, sehingga mahasiswa kurang aktif dan tidak bersemangat dalam belajar.Keluarga memiliki pengaruh yang sangat besar terhadap pembentukan karakter anak dan menjadi kunci utama dalam membentuk kepribadian anak sejak kecil hingga mereka dewasa. Ketika memasuki masa remaja, anak dengan berbagai sikap, perasaan, keterampilan, dan ketergantungan atas kehidupan awalnya. Maka diharapkan mereka akan keluar dari masa anak-anak dengan kesiapan penuh untuk menanggulanginya sebagai orang yang bertanggung jawab.

Selain dari metode pembelajaran yang kurang efektif, faktor lain yang juga berpengaruh terhadap hasil belajar mahasiswa adalah motivasi belajar. Motivasi belajar merupakan dorongan yang timbul dari dalam dan luar individu untuk melakukan perubahan tingkah laku. Motivasi belajar yang ada dalam diri mahasiswa yang satu dengan yang lain berbeda-beda, ada mahasiswa yang motivasi belajarnya tinggi dan ada juga yang motivasi belajarnya rendah. Seorang dosen harus mampu memilih metode pembelajaran yang tepat untuk mengajar. Apabila metode pembelajaran yang digunakan dosen itu tepat maka pencapaian hasil belajar akan lebih meningkat dan akan tercipta suasana pembelajaran yang menyenangkan serta mahasiswa termotivasi dalam belajar.

Banyak sekali metode pembelajaran yang dapat digunakan dalam proses belajar mengajar. Agar hasil yang dicapai memuaskan diperlukan metode pembelajaran yang tepat, yaitu metode yang dapat membangkitkan motivasi dan pemahaman mahasiswa terhadap matakuliah Logika Komputer. Salah satu upaya untuk membangkitkan motivasi dan pemahaman mahasiswa pada matakuliah Logika Komputer yaitu dengan penggunaan metode pembelajaran quiz team.

Pembelajaran quiz team merupakan salah satu pembelajaran aktif yang dikembangkan 
oleh Silberman dimana mahasiswa dibagi ke dalam 3 tim. Setiap mahasiswa dalam tim bertanggung jawab untuk menyiapkan kuis jawaban dan tim yang lain menggunakan waktu untuk memeriksa catatannya. Dengan adanya kompetisi antar kelompok, para mahasiswa akan senantiasa berusaha belajar dengan motivasi yang tinggi agar dapat memperoleh nilai yang lebih tinggi.

Berdasarkan latar belakang di atas maka judul untuk penelitian ini yaitu "Efektivitas Metode Pembelajaran Quiz Team Pada Matakuliah Logika Komputer Ditinjau dari Motivasi Belajar Mahasiswa STKIP PGRI Pontianak". Pada penelitian ini diharapkan metode pembelajaran Quiz Team dapat memberikan dampak hasil belajar yang lebih baik dan memberikan motivasi bagi siswa agar giat dalam belajar.

\section{Pembelajaran}

Menurut Hamalik (2003, p.61) pembelajaran adalah upaya mengorganisasikan lingkungan untuk menciptakan kondisi belajar bagi peserta didik. Di dalam pembelajaran adanya keterlibatan antara guru dan siswa yang saling berinteraksi serta siswa terlibat di dalam proses belajar. Dengan demikian guru hanya bertugas membantu peserta didik memperoleh informasi, ide, keterampilan, nilai, cara berpikir, sarana untuk mengekspresikan dirinya dan cara-cara bagaimana belajar.

Menurut Nitko \& Brokhart (2007, p.118) bahwa "Instruction is the process you use to provide stundents with the conditions that help them achieve the learning targets". Pembelajaran adalah proses yang digunakan untuk memberikan siswa kondisi yang membantu mereka mencapai target belajar. Guru sebagai fasilitator harus mampu mengorganisir semua unsur pembelajaran dan mengarahkannya kepada suasana yang memungkinkan seorang siswa untuk belajar, sehingga pencapaian hasil belajar lebih baik.

Pembelajaran saatini dituntutuntuk bersifat aktif, pembelajaran dinilai dari bagaimana para siswa terlibat dalam pembelajaran dan seberapa baik siswa berpartisipasi dalam pembelajaran tersebut. Proses pembelajaran tidak hanya transfer ilmu dari guru kepada siswa, melainkan suatu proses kegiatan, yaitu terjadi interaksi antara guru dengan siswa, antara siswa dengan siswa serta antara siswa dengan lingkungannya. Dengan demikian siswa lebih mandiri dalam belajar dan lebih mendalami materi yang diberikan oleh guru.

\section{Pembelajaran Aktif (Active Learning)}

Pembelajaran aktif (active learning) adalah suatu pembelajaran yang mengajak peserta didik untuk belajar secara aktif. Ketika peserta didik belajar dengan aktif, berarti mereka yang mendominasi aktifitas pembelajaran. Mereka secara aktif menggunakan otak mereka baik untuk menemukan ide pokok dari materi pelajaran, memecahkan persoalan atau mengaplikasikan apa yang baru mereka pelajari ke dalam suatu persoalan yang ada dalam kehidupan nyata (Hisyam Zaini, 2008, p.26).

Michael (2006, p.160) menyatakan pengertian pembelajaran aktif (active learning) adalah proses dimana siswa terlibat dalam beberapa kegiatan yang memaksa mereka untuk merenungkan ide-ide dan bagaimana mereka menggunakan ide-ide tersebut. Kegiatan yang mewajibkan siswa untuk secara teratur menilai tingkat pemahaman dan keterampilan mereka sendiri dalam memahami konsep atau menangani masalah dalam disiplin ilmu tertentu. Dalam pembelajaran aktif, siswa dilibatkan dalam proses pembelajaran agar mereka dapat berpikir kritis dan lebih mendalami materi sehingga dapat memecahkan masalah.

Menurut Machmudah (2008, p.72), secara umum dengan melakukan pembelajaran aktif (active learning) akan diperoleh halhal sebagai berikut: (1) interaksi yang menimbulkan ketergantungan positif (positive interdependence), (2) menciptakan tanggung jawab secara individu dalam kelompok (individual accountability), (3) memupuk rasa sosial antar siswa (sosial skill). Dengan pembelajaran aktif siswa tidak hanya sekedar mendengarkan informasi yang disampaikan oleh guru, akan tetapi siswa juga melihat apa yang dijelaskan oleh guru dan terakhir siswa melakukan atau mencobakan langsung apa yang telah dipelajari untuk memperoleh hasil belajar. 
Dengan demikian dapat diambil kesimpulan bahwa perlunya pembelajaran aktif perlu dilakukan karena dengan siswa terlibat secara aktif dengan mengatakan dan melakukan maka siswa akan lebih mudah untuk memahami materi serta dapat mengembangkan kreatifitas dan kemandirian siswa

\section{Metode Pembelajaran Quiz Team}

Quiz team merupakan model pembelajaran aktif yang dikembangkan oleh Silberman. Pada metode pembelajaran quiz team ini siswa dibagi menjadi tiga tim. Setiap siswa dalam tim bertanggung jawab untuk menyiapkan kuis jawaban singkat, dan tim yang lain menggunakan waktunya untuk memeriksa catatan (Silberman, 1996, p.175). Pada pembelajaran quiz team, siswa terlibat aktif dengan membuat kuis berupa pertanyaan dan jawaban yang nantinya akan dipertandingkan antar kelompok.

Silberman (2006, p.163) mengungkapkan prosedur pembelajaran aktif dengan menggunakan quiz team yaitu guru memilih topik yang disajikan dalam tiga segmen kemudian siswa dibagi ke dalam tiga kelompok besar. Guru menjelaskan skenario pembelajaran dan menyajikan materi pelajaran, kemudian guru meminta tim A untuk menyiapkan kuis jawaban singkat, sementara tim $B$ dan tim $C$ menggunakan waktu untuk memeriksa catatan mereka. Selanjutnya Tim A memberikan kuis kepada tim B, jika tim B tidak dapat menjawab pertanyaan, maka tim $\mathrm{C}$ segera menjawabnya. Kemudian Tim A mengarahkan pertanyaan berikutnya kepada anggota tim $\mathrm{C}$, dan mengulang proses tersebut. Ketika kuisnya selesai, lanjutkan segmen kedua dari pelajaran dan mintalah tim B sebagai pemandu kuis. Setelah tim B menyelesaikan kuisnya, lanjutkan dengan segmen ketiga dari pelajaran dan tunjuklah tim $\mathrm{C}$ sebagai pemandu kuis.

Metode pembelajaran quiz team merupakan salah satu acuan yang bisa diterapkan oleh guru untuk melakukan variasi strategi pembelajaran. Dengan adanya kompetisi antar kelompok, peserta didik akan mempunyai tanggung jawab yang sama serta saling memberikan motivasi agar dapat memperoleh skor yang tinggi dalam pertandingan. Metode pembelajaran quiz team dapat meningkatkan semangat belajar mahasiswa pada matakuliah Logika Komputer dan dapat meningkatkan hasil belajar mahasiswa. Mahasiswa akan merasa senang pada matakuliah Logika Komputer dan tidak ada yang beranggapan bahwa matakuliah Logika Komputer itu membosankan

\section{Metode Pembelajaran Konvensional}

Menurut Sagala (2007, p.187) pembelajaran konvensional adalah pembelajaran klasikal atau yang disebut juga pembelajaran tradisional. Pembelajaran klasikal adalah kegiatan penyampaian pelajaran kepada sejumlah siswa yang dibiasa dilakukan oleh pengajar dengan berceramah di kelas. Pembelajaran klasikal memandang siswa sebagai objek belajar yang hanya duduk dan pasif mendengarkan penjelasan guru. Menurut Suherman (2003, p.257) juga menjelaskan bahwa dalam pembelajaran klasikal guru sangat mendominasi dalam menentukan semua kegiatan pembelajaran. Pembelajaran klasikal tidak dapat melayani kebutuhan belajar siswa secara individu

Suatu pilihan yang realistik, ketika pembelajaran terpusat pada guru dan klasikal, metode ceramah dengan berbagai macam variasinya menjadi pilihan bagi seorang guru. Sehingga ceramah merupakan satu-satunya metodekonvensional danmasih tetap digunakan dalam strategi pembelajaran. Metode ini paling tua, paling banyak, dan sering digunakan dalam berbagai kesempatan. Kebanyakan guru memahami pembelajaran sebagai kegiatan menyampaikan pelajaran. Dengan pemahaman tersebut terciptanya kondisi pembelajaran satu arah, guru memberikan pelajaran peserta didik menerima pelajaran, guru berfungsi sebagai transmitter dan peserta didik sebagai receiver, (Gulo, 2004, pp. 136-137). Pola pembelajaran seperti ini menjadikan guru sebagai pusat pembelajaran dan metode ini merupakan metode klasikal.

Dalam pembelajaran konvensional, ada tahapan-tahapan proses pembelajaran yang dilakukan oleh guru. Menurut Sofyan, (2002, p.77) tahapan proses pembelajaran dengan strategi konvensional meliputi: (1) guru merumuskan tujuan pembelajaran; (2) 
guru menginformasikan materi dan tujuan pembelajaran; (3) guru menyajikan materi pembelajaran kepada peserta didik; (4) tanya jawab; dan (5) penugasan. Dari tahapan tersebut, terlihat bahwa siswa belum dilibatkan secara aktif dalam proses pembelajaran sehingga guru menjadi pusat pembelajaran.

Berdasarkan ciri-ciri di atas, dapat dikatakan bahwa pembelajaran yang selama ini dilaksanakan pada matakuliah Logika Komputer pada Program Studi PTIK termasuk masih konvensional. Berdasarkan hasil wawancara dengan dosen yang mengajar matakuliah Logika Komputer, prosedur pembelajaran pada matakuliah Logika Komputer dilaksanakan sebagai berikut: (1) setelah semua mahasiswa siap menerima materi pembelajaran, dosen menyampaikan kompetensi yang akan dipelajari; (2) dosen menyampaikan materi pembelajaran dengan ceramah dan menulis dipapan tulis; (3) setelah selesai menjelaskan dosen memberikan kesempatan kepada mahasiswa untuk bertanya; (4) dosen menanggapi dan membahas pertanyaan mahasiswa; (5) dosen mengakhiri materi pembelajaran dengan tugas, pekerjaan rumah atau sekedar mengucapkan salam penutup.

\section{Motivasi Belajar}

Menurut Donald yang dikutip oleh Hamalik (2004, p.173) bahwa "motivation is an energy change within the person characterized by affective arousal and anticipatory goal reaction", yang bearti bahwa motivasi adalah suatu perubahan energi dalam pribadi seseorang yang ditandai dengan timbulnya afektif dan reaksi untuk mencapai tujuan. Menurut Jex (2002, p.210) motivasi seperti gravitasi yang tidak bisa dilihat secara visual atau dirasakan namun hanya bisa dilihat efek yang dihasilkan olehnya. Pada kehidupan sehari-hari motivasi memiliki peran yang sangat strategis termasuk pada proses pembelajaran. Dimensi motivasi yang menggerakkan kebutuhan dan keinginan seseorang mampu menjelaskan apa yang membuat orang melakukan sesuatu, membuat mereka tetap melakukannya, dan membantu mereka dalam menyelesaikan tugas-tugas.

Menurut Brophy (2010, p.7) siswa cenderung mengalami motivasi intrinsik dalam kelas yang mendukung kepuasannya akan kebutuhan kemandirian, kompetensi, dan keterkaitan. Apabila bantuan tersebut kurang, siswa akan merasa dikontrol dari pada menentukan diri sendiri, sehingga motivasi mereka akan cenderung ekstrinsik bukan intrinsik. Siswa dalam pembelajaran harus memiliki motivasi intrinsik yang berasal dari dirinya sendiri secara sadar untuk mencapai tujuan pembelajaran. Selain motivasi intrinsik, motivasi ekstrinsik juga memiliki peran penting yang diakibatkan oleh pengaruh luar agar siswa lebih aktif dalam pembelajaran yang berdampak pada hasil belajar yang lebih baik. Oleh karena itu pentingnya motivasi intrinsik dan ekstrinsik ada pada diri siswa untuk memaksimalkan pencapaian tujuan pembelajaran.

Elliot(2000,p. 333) menyebutkan bahwa "In reality, the intrinsic extrinsic dichotomy is a false one. It is more accurate to say the student are primarily extrinsically motivated to learn". Dari pernyataan tersebut bearti bahwa pada kenyataannya, memisahkan antara faktor dari dalam dan dari luar merupakan suatu kesalahan. Yang lebih akurat untuk dikatakan bahwa siswa belajar dimotivasi dari dalam dirinya dan dari luar dirinya. Dari pengertian tersebut pentingnya motivasi dari dalam dan dari luar yang merupakan satu kesatuan sehingga mendorong siswa untuk mencapai tujuan yang telah ditetapkan sebelumnya.

Long \& Chen, (2013, p.136) menyatakan bahwa dorongan guru juga merupakan faktor penting untuk mempengaruhi penetapan tujuan dan tujuan-komitmen. Jika seorang siswa tidak memiliki kepercayaan diri, dorongan guru akan membantu siswa menyadari kemampuan atau keunggulan mereka sendiri, yang akan memotivasi siswa untuk menetapkan tujuan. Oleh karena itu, setiap individu harus menetapkan tujuan yang dapat menantang kesulitan; Namun, mereka tidak seharusnya di luar kemampuan mereka.

Motivasi dan belajar merupakan dua hal yang saling mempengaruhi. Belajar adalah perubahan tingkah laku secara relatif permanen dan secara potensial yang terjadi sebagai hasil dari praktik atau penguatan (reinforced practice) yang dilandasi tujuan untuk mencapai 
tujuan tertentu. Dimyati dan Mudjiono (2006, p.80) menyatakan bahwa kekuatan mental yang mendorong terjadinya belajar tersebut disebut motivasi belajar. Hamzah (2008, p.23) menyatakan bahwa hakekat motivasi belajar adalah dorongan internal dan eksternal pada siswa-siswi yang sedang belajar untuk mengadakan perubahan tingkah laku. Dari beberapa pendapat para ahli dapat disimpulkan motivasi belajar adalah dorongan dari dalam dan dari luar pada siswa sehingga terjadi perubahan tingkah laku.

\section{Hasil Belajar}

Menurut Hilgard yang dikutip oleh Sanjaya, (2010, pp. 228-229) "Learning is process by which an activity originates or changed through training procedures (wether in laboratory or in the natural environtment) as distinguished from changes by factors not attributable to training". Hasil belajar merupakan kemampuan yang diperoleh individu setelah proses pembelajaran berlangsung, yang dapat memberikan perubahan tingkah laku baik pengetahuan, pemahaman, sikap dan keterampilan siswa sehingga menjadi lebih baik dari sebelumnya. Pendapat tersebut didukung oleh Sanjaya (2010, p.229) bahwa hasil belajar adalah suatu proses aktivitas mental seseorang dalam berinteraksi dengan lingkungannya sehingga menghasilkan perubahan tingkah laku yang bersifat positif, oleh karena perubahan perilaku itu bersifat adanya penambahan dari perilaku sebelumnya yang cenderung menetap (tahan lama dan tidak mudah dilupakan).

Hasil belajar mata pelajaran merupakan tingkat kemampuan yang dapat dikuasai dari materi yang telah diajarkan. Hasil belajar mencakup lima kemampuan sebagaimana yang telah diungkapkan oleh Gagne yang dikutip oleh Sanjaya, (2010, pp.233-234) bahwa tingkat kemampuan atau penugasan yang dapat dikuasai oleh siswa mencakup lima aspek yaitu: (1) belajar kemahiran intelektual (kognitif), (2) belajar informasi verbal, (3) belajar mengatur kegiatan intelektual, (4) belajar sikap, dan (5) belajar keterampilan motorik. Dari kelima kemampuan ini dijadikan dasar sebagai kemampuan yang harus dimiliki oleh siswa untuk selanjutnya dijadikan sebagai dasar dalam menempuh pembelajaran selanjutnya.
Berdasarkan pengertian di atas maka dapat disimpulkan bahwa hasil belajar adalah suatu penilaian akhir dari proses dan pengenalan yang telah dilakukan berulangulang serta akan tersimpan dalam jangka waktu lama atau bahkan tidak akan hilang selamalamanya karena hasil belajar turut serta dalam membentuk pribadi individu yang selalu ingin mencapai hasil yang lebih baik lagi sehingga akan merubah cara berpikir serta menghasilkan perilaku kerja yang lebih baik lagi.

\section{METODE PENELITIAN}

\section{Jenis dan Desain Penelitian}

Penelitian ini termasuk jenis penelitian kuantitatif dengan pendekatan quasiexperiment (eksperimen semu), yaitu penelitian eksperimen tetapi subjek penelitian tidak dipilih secara acak (random) sepenuhnya (Sukardi, 2003, p.184). Subjek penelitian ini yaitu kelas eksperimen dan kelas kontrol yang tidak dipilih secara acak. Penelitian ini bertujuan untuk mengetahui pengaruh metode pembelajaran quiz team pada proses pembelajaran matakuliah Logika Komputer. Tujuan khusus dari penelitian ini adalah untuk mengetahui perubahan hasil belajar matakuliah Logika Komputer. Desain eksperimen yang digunakan dalam penelitian ini adalah nonequivalent comparison-group design. Pada desain penelitian ini kelompok eksperimen maupun kelompok kontrol tidak dipilih secara random. Hanya kelasnya yang diacak dari 6 kelas dipilih 2 kelas sebagai kelas kontrol dan kelas ekperimen.

\section{Tempat dan Waktu Penelitian}

Penelitian ini dilakukan di STKIP PGRI Pontianak yang terletak di provinsi Kalimantan Barat. Penelitian dilaksanakan pada semester genap (II) tahun pelajaran 2014 yang akan dimulai pada bulan Maret hingga April 2014.

\section{Subjek Penelitian}

Subjek penelitian yaitu mahasiswa semester II tahun akademik 2013/2014 yang tercatat sebagai mahasiswa aktif Prodi PTIK di STKIP PGRI Pontianak. Populasi penelitian berjumlah 215 orang. Sampel yang digunakan 
dalam penelitian ini penelitian berjumlah 2 kelas yaitu 1 kelas eksperimen dan 1 kelas kontrol. Kelas eksperimen yaitu C Pagi sebanyak 33 mahasiswa, kelas kontrol yaitu kelas B Pagi sebanyak 35 mahasiswa. Total sampel dari 2 kelas tersebut sebanyak 68 mahasiswa. Sesuai dengan desain kuasi eksperimen yaitu nonequivalent comparison-group design maka penentuan sampel didasarkan pada kelas yang telah terbentuk sebelumnya.

\section{Prosedur}

Penelitian kuasi eksperimen dilakukan selama 6 minggu (6 kali pertemuan) dimulai dari tanggal 9 Maret - 15 April 2014. Matakuliah yang difokuskan pada penelitian ini adalah Logika Komputer dengan 3 kompetensi dasar yaitu menjelaskan pengantar logika matematika, menjelaskan logika proporsional, dan memahami tabel kebenaran dalam logika. Desain penelitian yang digunakan yaitu Nonequivalent Comparison-group Design, dimana desain penelitian ini memiliki kelas kontrol dan kelas ekperimen, serta setiap kelas diberikan pretest dan posttest. Kelas eksperimen diterapkan metode pembelajaran quiz team dan kelas kontrol diterapkan metode pembelajaran konvensional. Sebelum eksperimen ini dilakukan, diberikan pretest untuk mengukur kemampuan awal mahasiswa baik dikelas eksperimen maupun dikelas kontrol, setelah itu diberikan posttest untuk mengukur hasil belajar mahasiswa baik dikelas eksperimen maupun kontrol.

\section{Data, Instrumen, dan Teknik Pengumpulan Data}

Beberapa data yang dikumpulkan dalam penelitian ini adalah data motivasi belajar dan data hasil belajar. Teknik pengumpulan data berupa non tes dan tes. Instrumen non tes berupa angket untuk mengukur motivasi belajar. Instrument non tes ini diberikan sebelum eksperimen untuk mengetahui motivasi belajar. Instrumen tes tertulis berupa pilihan ganda yang digunakan untuk mengukur variabel hasil belajar mahasiswa dalam matakuliah Logika Komputer. Tes ini dilakukan dua kali yaitu pretest dan posttest. Pretest dilakukan untuk mengetahui kemampuan awal mahasiswa dan posttest digunakan untuk mengetahui hasil belajar mahasiswa.

\section{Teknik Analisis Data}

Teknik analisis data menggunakan analisis varian dua jalur (Anava dua jalur). Anova dua arah digunakan bila dalam analisis data ingin mengetahui ada atau tidak perbedaan dari dua variabel, sedangkan masing-masing variabel dibagi dalam beberapa kelompok. Penelitian ini menguji perbedaan antara dua kelompok dengan perlakuan dua jenis pendekatan pembelajaran. Disamping itu kedua kelompok mahasiswa dibedakan antara mahasiswa yang memiliki motivasi tinggi dan mahasiswa yang memiliki motivasi rendah.

\section{Uji Persyaratan Analisis}

Sebelum uji hipotesis dilakukan, maka harus dilakukan uji kesamaan kemampuan awal dan uji prasyarat (normalitas dan homogenitas). Uji kesamaan kemampuan awal dilakukan untuk mengetahui apakah kedua kelompok (kelompok quiz team dan kelompok konvensional) dalam keadaan sama atau tidak. Statistik uji yang digunakan dalam uji keseimbangan adalah uji-t. Uji normalitas bertujuan untuk mengetahui apakah suatu variabel berdistribusi normal atau tidak. Normal atau tidaknya variabel berdasarkan pada patokan dari distribusi normal dari data dengan mean dan standar deviasi yang sama. Menurut Sugiyono (2011, p.241) penggunaan statistik parametris mensyaratkan bahwa data setiap variabel yang akan dianalisis harus berdistribusi normal. Oleh karena itu sebelum uji hipotesis dilakukan, maka terlebih dahulu dilakukan pengujian normalitas data. Untuk menganalisis data tersebut digunakan bantuan SPSS versi 16.00. Dalam pengujian uji normalitas menggunakan One-Sample Kolmogorov-Smirnov. Selain uji normalitas maka uji homogenitas juga menjadi prasyarat sebelum pengujian hipotesis dilakukan. Uji ini bertujuan untuk mengetahui apakah kedua kelas yang dijadikan penelitian merupakan kelas yang seimbang (homogen). Uji homogenitas dibantu dengan SPSS 16.00. Uji homogenitas menggunakan uji Levene test.

\section{Menguji Hipotesis Penelitian}

Uji hipotesis yang pertama dan ketiga digunakan teknik analisis anava dua jalur sedangkan untuk menguji hipotesis kedua 
digunakan teknik analisis anava dua jalur tahap lanjut dengan uji scheffe.

\section{HASIL PENELITIAN DAN PEMBAHASAN}

Hasil penelitian disajikan berdasarkan data yang diperoleh selama penelitian. Berikut ini disajikan data motivasi belajar dan hasil belajar mahasiswa.

\section{Motivasi belajar secara keseluruhan}

Skor motivasi belajar mahasiswa secara keseluruhan diperoleh mean 114,32, median 114,50, skor minimum 99 dan skor maksimum134. Histogram motivasi belajar dapat dilihat pada Gambar 1.

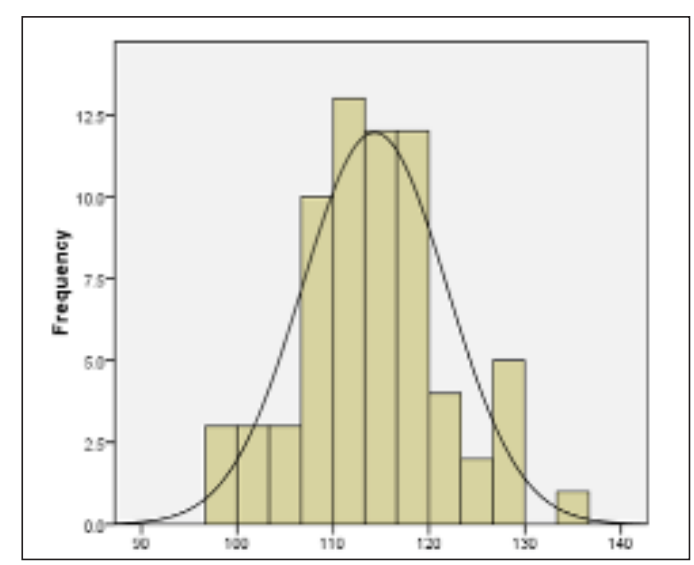

Gambar 1. Histogram Motivasi Belajar secara keseluruhan

\section{Hasil belajar kelas eksperimen}

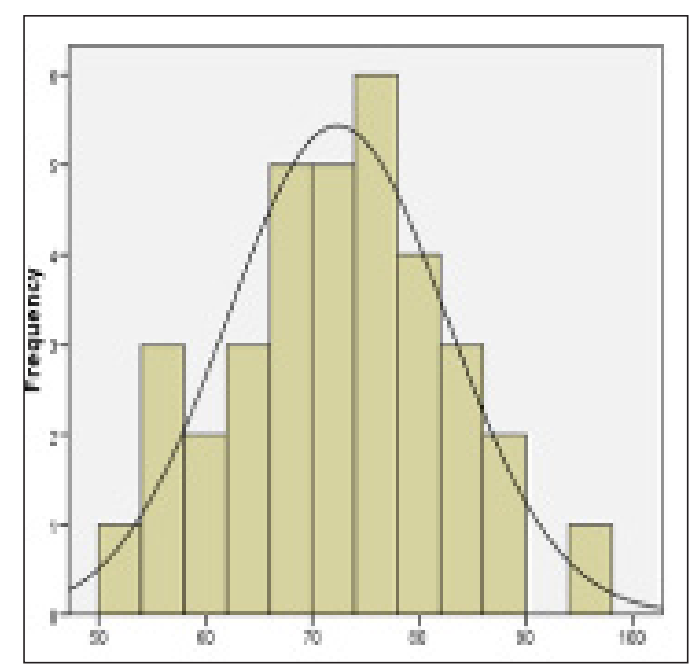

Gambar 2. Histogram Hasil Belajar Kelas Eksperimen
Hasil belajar mahasiswa kelas eksperimen diperoleh mean 72,34, median 72.34, modus 76 , standar deviasi 10,28 , skor minimum 52 dan skor maksimum 96. Histogram hasil belajar kelas eksperimen dapat dilihat pada Gambar 2.

\section{Hasil belajar kelas kontrol}

Hasil belajar mahasiswa kelas kontrol diperoleh mean 62,36 , median 60 , modus 60 , standar deviasi 10,90, skor minimum 44 dan skor maksimum 84. Histogram hasil belajar kelas kontrol dapat dilihat pada Gambar 3.

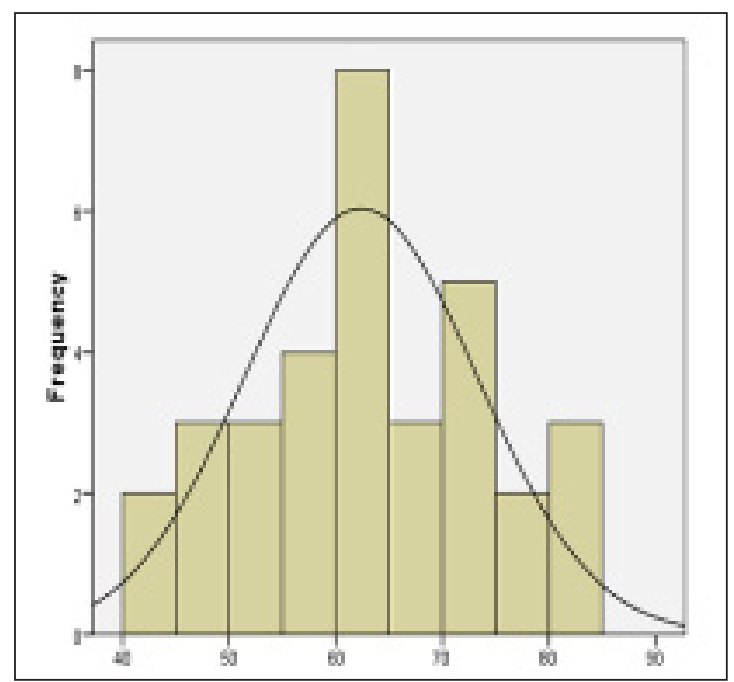

Gambar 3. Histogram hasil belajar kelas kontrol

\section{Pengelompokkan Anggota Sampel Ber- dasarkan Motivasi Tinggi dan Rendah}

Hasil skor keseluruhan yang diperoleh dari angket motivasi belajar mahasiswa kemudian dirangking dari yang terbesar hingga terkecil. Setelah dirangking, kemudian data dikelompokkan, untuk kelompok atas dinyatakan sebagai kelompok yang memiliki motivasi belajar tinggi sedangkan kelompok bawah dinyatakan sebagai kelompok yang memiliki motivasi belajar rendah

Tabel 1. Komposisi Anggota Sampel

\begin{tabular}{lll}
\hline \multicolumn{1}{c}{$\begin{array}{c}\text { Kelompok } \\
\text { Mahasiswa }\end{array}$} & $\begin{array}{c}\text { Quiz } \\
\text { Team }\end{array}$ & Konvensional \\
\hline Motivasi Tinggi & 17 & 14 \\
Motivasi Rendah & 18 & 19 \\
Total & 35 & 33 \\
\hline
\end{tabular}


Tabel 2. Deskripsi Hasil Belajar Mahasiswa (Posttest)

\begin{tabular}{lccc}
\hline Sumber Statistik & & Quiz Team & Konvensional \\
\hline Motivasi tinggi & $\mathrm{N}$ & 17 & 14 \\
& $\bar{X}$ & 74,35 & 63,14 \\
& $\mathrm{~S}$ & 7,88 & 10,07 \\
& Min & 60 & 48 \\
& Max & 88 & 80 \\
\hline Motivasi Rendah & $\mathrm{N}$ & 18 & 19 \\
& $\mathrm{X}$ & 70 & 62 \\
& $\mathrm{~S}$ & 11,98 & 11,49 \\
& Min & 52 & 44 \\
Hasil belajar eksperimen dan konvensional & Max & 96 & 72 \\
\hline & $\mathrm{N}$ & 35 & 33 \\
& $\mathrm{X}$ & 72,34 & 62,36 \\
& $\mathrm{~S}$ & 10,28 & 10,90 \\
& Min & 52 & 44 \\
& Max & 96 & 84 \\
\hline
\end{tabular}

Tabel 3. Uji kemampuan awal dan uji prasyarat analisis

\begin{tabular}{lcc}
\hline Data & Hasil & Keputusan \\
\hline pretest & 0,286 & Kemampuan awal sama \\
Posttest eksperimen & 0,200 & Normal \\
Posttest kontrol & 0,193 & Normal \\
Posttes Motivasi tinggi (eksperimen) & 0,200 & Normal \\
Postest Motivasi rendah (eksperimen) & 0,200 & Normal \\
Postest Motivasi tinggi (kontrol) & 0,200 & Normal \\
postestMotivasi rendah (kontrol) & 0,120 & Normal \\
Posttest Kontrol dan eksperimen & 0,188 & Homogen \\
\hline
\end{tabular}

Tabel 4. Rangkuman Hasil Analisis Variansi Dua Jalur

\begin{tabular}{lcc}
\hline Sumber Varian & $\mathbf{F}_{\text {ratio }}$ & Peluang Kesalahan \\
\hline Antar Kolom (Pembelajaran) & 14,788 & 0,000 \\
Antar Baris (Motivasi) & 6,426 & 0,037 \\
Kolom dan Baris (Interaksi & 0,450 & 0,505 \\
\hline
\end{tabular}

\section{Deskripsi Data Hasil Belajar Berdasarkan Motivasi Tinggi dan Rendah.}

Deskripsi hasil belajar mahasiswa (Posttest) dapat dilihat pada tabel 2.

\section{Uji kemampuan awal dan uji prasyarat analisis}

Sebelum uji hipoteis dilakukah langkah pertama yang dilakukan yaitu menguji kemampuan awal subjek penelitian dengan melakukan pretest guna memperoleh data awal kemudian dilakukan uji prasyarat analisis yaitu uji normalitas dan homogenitas. Lebih lengkapnya dapat dilihat pada Tabel 3.

\section{Pengujian Hipotesis Penelitian}

Setelah uji persyaratan analisis untuk statistik parametris terpenuhi, maka data penelitian akan diuji dengan dua teknik analisis pengujian hipotesis yaitu pengujian hipotesis 
Tabel 5. Hasil Anava Tahap Lanjut dengan Uji Scheffe

\begin{tabular}{lcc}
\hline Kelompok yang diperbandingkan & P value & Keterangan \\
\hline$\overline{\mathrm{X}} \mathrm{A}_{1} \mathrm{~B}_{1}$ dan $\overline{\mathrm{X}} \mathrm{A}_{2} \mathrm{~B}_{1}$ & $0,042<0,05$ & Signifikan \\
$\overline{\mathrm{X}} \mathrm{A}_{1} \mathrm{~B}_{2}$ dan $\overline{\mathrm{X}} \mathrm{A}_{2} \mathrm{~B}_{2}$ & $0,032<0,05$ & Signifikan \\
\hline
\end{tabular}

menggunakan analisis anava dua jalur dan uji scheffe. Hasi analisis anava dua jalur dapat pada Tabel 4.

Berdasarkan rangkuman hasil analisis variansi dua jalur pada tabel 2 di atas maka dapat dirumuskan hasil uji hipotesis sebagai berikut.

\section{Hipotesis pertama}

Dari tabel di atas diperoleh $\mathrm{F}_{\text {ratio }}$ untuk faktor pembelajaran sebesar 14,788. Apabila angka ini dikonfirmasikan dengan $\mathrm{F}_{\text {tabel }}$ dengan taraf signifikansi $0,05(5 \%)$, dmana dk nya 1 untuk pembilang dan 64 untuk penyebut, diperoleh angka 3,99 maka terlihat bahwa $\mathrm{F}$ tabel lebih kecil dari $\mathrm{F}_{\text {ratio }}$ yang berarti hipotesis alternatif yang menyatakan bahwa terdapat perbedaan hasil belajar antara mahasiswa yang diajar dengan metode pembelajaran quiz team dan mahasiswa yang diajar dengan metode konvensional diterima. Dari data yang diperoleh pada tabel 2, rata-rata hasil belajar metode pembelajaran quiz team mempunyai perbedaan yang signifikan dibandingkan dengan metode konvensional, Rata-rata hasil belajar mahasiswa yang diajar dengan metode quiz team $\left(\overline{\mathrm{X}}_{1}=72,34\right)$ dan untuk metode konvensional $\left(\mathrm{XA}_{2}=62,36\right)$.

\section{Hipotesis Kedua}

Analisis Anava tahap lanjut yaitu uji Scheffe untuk melihat perbedaan hasil belajar antara kelompok eksperimen dan kontrol ditinjau dari motivasi. Hasil uji scheffe pada taraf signifikansi 0,05 dirangkum pada Tabel 5 .

Pada kelompok $\bar{X}_{1} \mathrm{~B}_{1}$ dan $\bar{X}_{2} \mathrm{~B}_{1}$ harga $\mathrm{p}$ value $=0,042<0,05$ berarti $\mathrm{H} 0$ ditolak dan $\mathrm{Ha}$ diterima, Dengan demikian ada perbedaan hasil belajar matakuliah Logika Komputer antara kelas yang menggunakan metode pembelajaran quiz team serta kelas yang menggunakan metode pembelajaran konvensional ditinjau dari mahasiswa yang memiliki motivasi tinggi.
Dari data yang diperoleh pada Tabel 2, ratarata hasil belajar metode pembelajaran quiz team mempunyai perbedaan yang signifikan dibandingkan dengan metode konvensional, Rata-rata metode pembelajaran quiz team lebih besar dibandingkan dengan metode konvensional $\left(\overline{\mathrm{X}_{1}} \mathrm{~B}_{1}=74,35>\overline{\mathrm{X}} \mathrm{A}_{2} \mathrm{~B}_{1}=63,14\right)$.

Pada kelompok $\mathrm{A}_{1} \mathrm{~B}_{2}$ dan $\mathrm{A}_{2} \mathrm{~B}_{2}$ harga p value $=0,032<0,05$ berarti $\mathrm{H} 0$ ditolak dan $\mathrm{Ha}$ diterima, Dengan demikian ada perbedaan hasil belajar matakuliah Logika Komputer antara kelas yang menggunakan metode pembelajaran quiz team serta kelas yang menggunakan metode pembelajaran konvensional ditinjau dari mahasiswa yang memiliki motivasi rendah, Dari data yang diperoleh pada tabel 2, rata-rata hasil belajar metode pembelajaran quiz team mempunyai perbedaan yang signifikan dibandingkan dengan metode konvensional. Rata-rata hasil belajar mahasiswa yang diajar dengan metode pembelajaran quiz team lebih besar dibandingkan dengan metode konvensional $(\overline{\mathrm{X}}$ $\mathrm{A}_{1} \mathrm{~B}_{2}=72,34>\overline{\mathrm{X}} \mathrm{A}_{2} \mathrm{~B}_{2}=62,36$ ),

\section{Hipotesis ketiga}

Dari tabel 4 diperoleh $\mathrm{F}_{\text {ratio }}$ untuk faktor interaksi sebesar 0,450. Apabila angka ini dikonfirmasikan dengan $\mathrm{F}$ tabel dengan taraf signifikansi 0,05 (5\%), dmana dk nya 1 untuk pembilang dan 64 untuk penyebut, diperoleh angka 3,99 maka terlihat bahwa $\mathrm{F}$ tabel lebih kecil dari $\mathrm{F}_{\text {ratio }}$ maka hipotesis alternatif yang menyatakan bahwa ada interaksi antara metode pembelajaran dan motivasi belajar mahasiswa dalam pengaruhnya dalam pencapaian hasil belajar mahasiswa ditolak, Sedangkan hipotesis $\mathrm{H}_{0}$ yang menyatakan bahwa tidak ada interaksi antara metode pembelajaran dan motivasi belajar terhadap pencapaian hasil belajar mahasiswa diterima. 


\section{SIMPULAN DAN SARAN}

\section{Simpulan}

Berdasarkan data dan pembahasan yang diperoleh pada penelitian ini dapat disimpulkan secara keseluruhan hasil belajar mahasiswa pada matakuliah Logika Komputer, mahasiswa yang menggunakan metode quiz team lebih tinggi dibanding dengan metode pembelajaran konvensional. Dari hasil ini dapat dikatakan bahwa untuk meningkatkan hasil belajar pada matakuliah Logika Komputer sebaiknya menggunakan metode pembelajaran quiz team.

Ditinjau dari mahasiswa yang memiliki motivasi tinggi, ada perbedaan hasil belajar antara mahasiswa yang diajar dengan metode quiz team dan metode konvensional. Ditinjau dari mahasiswa yang memiliki motivasi rendah, ada perbedaan hasil belajar antara mahasiswa yang diajar dengan metode quiz team dan metode konvensional.

Tidak terdapat interaksi antara metode pembelajaran dan motivasi belajar terhadap hasil belajar Logika Komputer. Hal ini dapat dilihat dari gambar interaksi antara metode pembelajaran dan motivasi belajar tidak ada garis saling bersinggungan atau antar garis tidak memotong.

\section{Saran}

Dosen tidak hanya mengajar matakuliah Logika Komputer dengan metode konvensional saja, tetapi berinovasi menggunakan berbagai metode yang dapat mengaktifkan mahasiswa salah satunya dengan menggunakan metode pembelajaran quiz team. Metode pembelajaran quiz team dalam pelaksanaannya, dosen harus memperhatikan waktu pembagian setiap tim agar tidak memakan waktu yang lama. Dosen harus memastikan bahwa mahasiswa sudah memahami langkah-langkah metode pembelajaran quiz team agar keaktifan mahasiswa dapat terkontrol.

Lembaga STKIP PGRI Pontianak hendaknya memberikan penyuluhan kepada para dosen supaya dalam mengajar tidak hanya menggunakan metode konvensional saja, tetapi divariasikan dengan metode pembelajaran aktif, salah satunya metode pembelajaran quiz team untuk meningkatkan hasil belajar mahasiswa

\section{DAFTAR PUSTAKA}

Brophy, J. (2010). Motivating students to learn ( $3^{\text {rd }}$ ed.). New York: Routledge.

Dimyati dan Mudjiono. (2006). Belajar dan Pembelajaran. Jakarta: Rineka Cipta

Elliot. (2000). Educational psychology effective teaching, effective learning. New York: Mc. Graw Hill.

Gagne, R., \& Briggs, LJ. (1978). Principles of instructional design. Chicago: Holt, Rinenart and Winston

Gulo, W. (2004). Strategi Belajar Mengajar. Jakarta: Grasindo

Hamzah B. Uno. (2008). Teori motivasi dan pengukurannya. Jakarta: Bumi Aksara

Sofyan, H. (2002). Pengaruh strategi pembelajaran dan gaya berpikir siswa terhadap hasil belajar motor otomotif. Disertasi. Jakarta: Universitas Negeri Jakarta

Jex, S.M. (2002). Organizational psychology: a scientist-practitioner approach. New York: John Wiley \& Sons

Long, C. Ming, Z. \& Chen, L. (2013). The study of student motivation on english learning in junior middle school. Canadian Center of Science and Education, 6, 136-145.

Machmudah, U. (2008). Active Learning Dalam Pembelajaran Bahasa Arab. UIN-Malang Press

Michael, J. (2006). Where's the evidence that active learning works?. Advan in Physiol Education, 30:159-167. Diambil pada tanggal 7 Juli 2014 dari http:// advan.physiology.org/content/30/4/159. full.pdf $+\mathrm{html}$

Nitko, A. J. \& Brookhart, S.M. (2007). Educational assessment of Students. $\left(5^{\text {th }} e d\right)$. Upper Saddle River NJ: Pearson Educational.

Sagala, S. (2007). Konsep dan Makna Pembelajaran. Bandung: CV. Alfabeta 
Silberman. (1996). 101 Strategies To Teach Any Subject. Massachusetts: A Simon \& Schuster Company.

Silberman, Melvin L. (2006). Active Learnig 101 Cara Belajar Siswa Aktif. Bandung: Nusa Media.

Suherman, E dkk., 2003, Strategi Pembelajaran Matematika Kontemporer, Jakarta: Universitas Pendidikan Indonesia
Sugiyono. 2011. Metode Penelitian Pendidikan, Bandung: Alfabeta.

Sanjaya, W (2010). Kurikulum dan Pembelajaran: Teori dan praktik pengembangan kurikulum tingkat satuan pendidikan (KTSP). Jakarta: Kencana Prenada Media Group

Zaini, H. 2008. Strategi Pembelajaran Aktif. Yogyakarta: Pustaka Insan Madani 